\title{
Compositional and textural peculiarities of gold-rich alloys from the Merensky Reef
}

\author{
Roland Merkle, Wiebke Grote and Peter Gräser \\ Bushveld Intelligence Center, Department of Geology, University of Pretoria, Pretoria 0002, South Africa. \\ e-mail: rmerkle@postino.up.ac.za; wiebke.grote@up.ac.za \\ peter.graser@up.ac.za
}

(c) 2008 September Geological Society of South Africa

\begin{abstract}
Gold-rich alloys with variable amounts of Pd from the Merensky Reef, Bushveld Complex, are characterized by a range of finely dispersed inclusions. The small sizes of these inclusions (median of $1.85 \mu \mathrm{m}$ ) make fully quantitative analyses virtually impossible. Tentative interpretation of semi-quantitative microprobe analyses demonstrates the presence of atokite, kotulskite, laurite, moncheite, niggliite, paolovite, rustenburgite, sobolevskite, and sperrylite. Some inclusions appear to represent unnamed minerals.

Textures and assemblages imply that these gold grains and their inclusions formed from fluids through occasional remobilisation and co-precipitation.
\end{abstract}

\section{Introduction}

The Merensky Reef of the Bushveld Complex is not only a major source of platinum-group elements (PGE), it also contains gold which is recovered as a by-product. Very little information about the concentrations and distribution of gold in the Merensky Reef is available, but the recommended value for Au in SARM-7, an international standard for PGE which was prepared from Merensky Reef (Steele et al., 1975), is $310 \pm 0.015 \mathrm{ppb}$ for the $95 \%$ confidence interval, and an average value for $\mathrm{Au}$ in the Merensky Reef was reported to be $220 \mathrm{ppb}$ (Vermaak, 1976). Regional variation in gold concentration is linked to variations in $\Sigma \mathrm{PGE}+\mathrm{Au}$ grade (Viljoen, 1994; 1999) and to variable proportions of Au ( 1.5 to $6.6 \%$ of $\Sigma \mathrm{PGE}+\mathrm{Au}$ ) in different types of Merensky Reef (Leeb-Du Toit, 1986; Viljoen and Hieber, 1986; Farquhar, 1986; Mossom, 1986; Viljoen et al., 1986a; 1986b).

Even in single boreholes through the Merensky Reef (ignoring differences in rock types) with an average Aucontent of $460 \mathrm{ppb}$ (Von Gruenewaldt et al., 1990) and $570 \mathrm{ppb}$ (Barnes and Maier, 2002) respectively, individual samples were found to vary between $<50$ and $>2000 \mathrm{ppb}$ (Barnes and Maier, 2002; Wilson and Chunnett, 2006). Tin contents in the Merensky Reef are assumed to be about $2 \mathrm{ppm}$ (Vermaak, 1976), while silver may reach $1.4 \mathrm{ppm}$ in individual samples (Barnes and Maier, 2002) with a large scale average of $0.54 \mathrm{ppm}$ (Vermaak, 1976). Gold shows positive correlations with $\mathrm{Ag}, \mathrm{Pt}$, and $\mathrm{Pd}$, but the number of reported analyses is too small to allow a rigorous evaluation of variations between the different rock types that make up the Merensky Reef (i.e. the economically mineable PGE ore, irrespective of the rock type). It is reasonable to assume that different rock types of the Merensky Reef are petrologically and genetically different (Cawthorn and Boerst, 2006).

Mineralogical descriptions mention the occurrence of metallic gold and electrum (Mihálik et al., 1975; Schwellnus et al., 1976; Brynard et al., 1976; Vermaak and Hendriks, 1976; Kingston and El-Dosuky, 1982; Mostert et al., 1982; Franklyn and Merkle, 1999) in the Merensky Reef. For simplicity, all these grains will be referred to as metallic gold in this communication, irrespective of the $\mathrm{Au} / \mathrm{Ag}$ ratio. Most of these grains are very small. Volume proportions of metallic gold amongst $\mathrm{PGE}$ and Au-containing minerals range typically from traces to 4.1\% (Brynard et al., 1976; Vermaak and Hendriks, 1976; Kinloch, 1982), although in individual boreholes the proportion of $\mathrm{Au}-\mathrm{Ag}$ alloys may exceed 40\% (Kinloch, 1982).

Large metallic gold grains of up to $500 \mu \mathrm{m}$ in length and up to $100 \mu \mathrm{m}$ in thickness can be found in Merensky Reef concentrate. A microscopic investigation of such grains from Rustenburg Platinum Mine (Kingston and El-Dosuky, 1982) revealed that many of them contain variable amounts of tiny inclusions which were identified to be atokite and mertieite II. Such inclusions are not restricted to Rustenburg Platinum Mine and can be observed in coarse metallic gold from around the Bushveld Complex and have even been observed in detrital gold from the eastern Bushveld drainage system (Oberthür et al., 2004).

The information presented here is based on observations of $\sim 250$ gold grains handpicked from production concentrate, with the main emphasis on the composition of the metallic gold, associations and types of inclusions, and micro-textures. Because such concentrates are dependent on the mining operation at a specific time, they are representative for a large volume of Merensky Reef. They can, however, not be taken to be representative for the Merensky Reef per se. The concentrate was put at our disposal under the condition that its source may not be revealed.

\section{Analytical Conditions}

Electron microprobe analyses were performed with a JEOL 733 electron microprobe and attached ISIS energy dispersive system with an accelerating potential of $20 \mathrm{kV}$ and a beam current of $2 \times 10^{-8} \mathrm{~A}$. We decided on this 


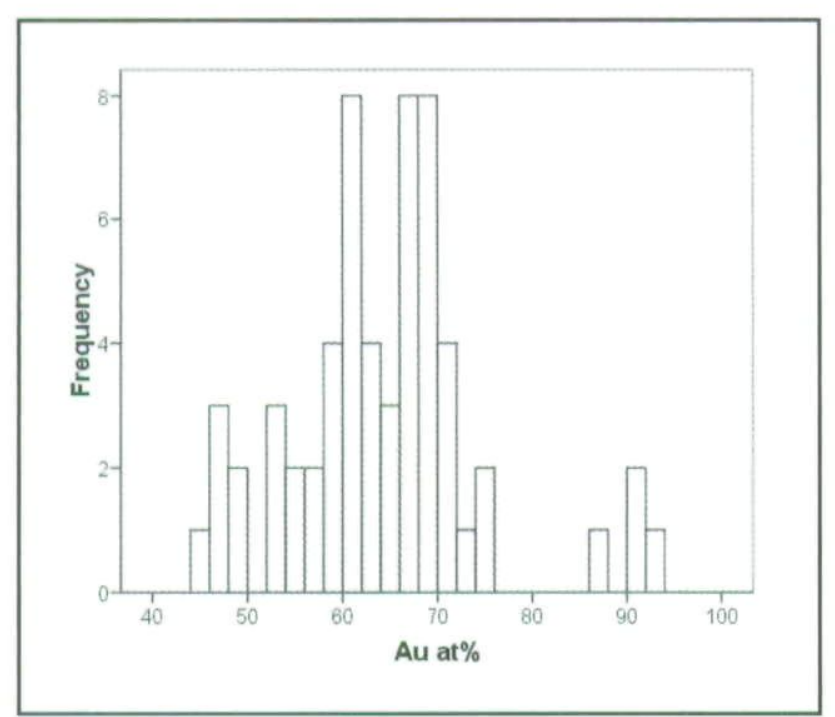

Figure 1. Frequency distribution of Au content in gold-rich alloys.

approach because this allows to store the spectrum of any analysis and to process it with combinations of different standards. Because of the very small grain sizes of most inclusions in the metallic gold, it had to be expected that most analyses will represent mixtures of a range of platinum-group minerals (PGM) with metallic gold of varying $\mathrm{Au} / \mathrm{Ag}$ ratios. Such complex variations in the matrix cause a multitude of problems, of which the non-linear determination in mixtures of $\mathrm{Au}$ and $\mathrm{Ag}$ (Reid et al., 1988), or Pt and Pd (Merkle and Verryn, 1991) are just two. Correction procedures (mainly absorption and fluorescence) in electron microprobe analysis assume that the analyzed material is homogeneous and all elements are evenly distributed throughout the excitation volume from which X-rays are produced (Reed, 1975). Analyses (i.e., excitation areas) that represent two or more distinct phases inevitably lead to incorrect results.

Attempts to produce metallic standards with complex matrices failed because heterogeneities on $\mu \mathrm{m}$-scale could not be overcome. Suitable standards close to the unknown, which are required to achieve very good quality results in complex matrices (Cabri, 1980), were therefore not available. We had to resort to a large range of metals, alloys, and synthetic PGM in attempts to approach the matrix in question. Consequently, many analyses are too low and in some cases, element ratios appear to be represented inaccurately. Even if totals of the microprobe analyses approach totals of $100 \%$, we consider this to be coincidence and the analyses are considered to be only semi-quantitative. We therefore refrain from any interpretation of small variations of composition or stoichiometry, but consider the analyses perfectly acceptable for the tentative identification of the phases.

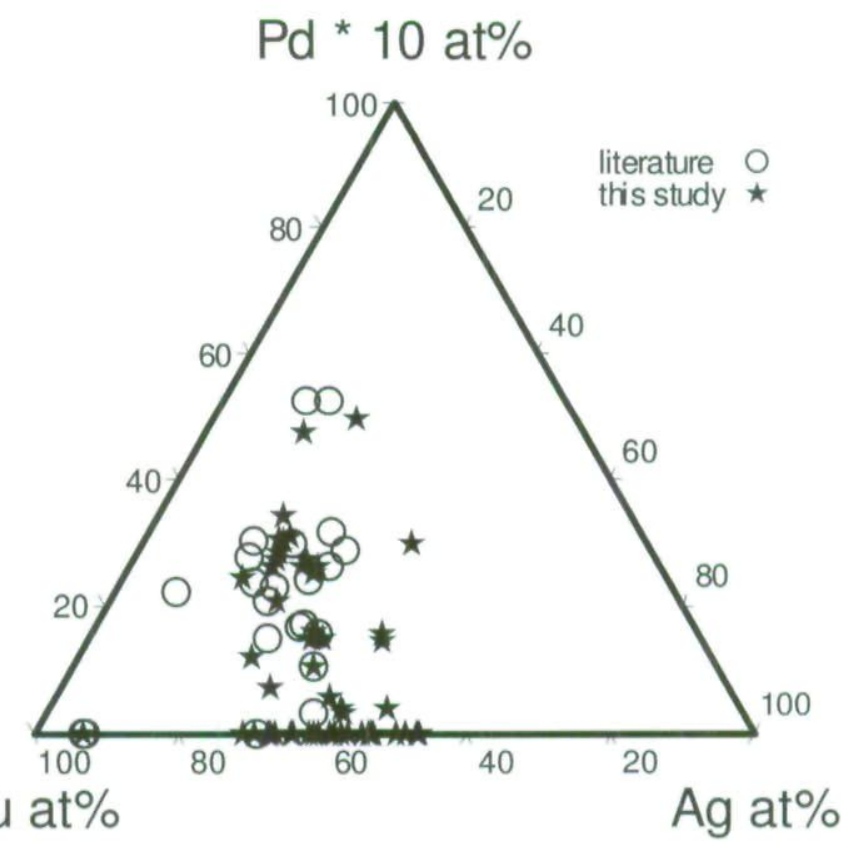

Figure 2. Compositional variation of gold-rich alloy from Merensky Reef concentrate. Literature data from Kingston \& El-Dosuky (1982) and Schwellnus et al., (1976). 

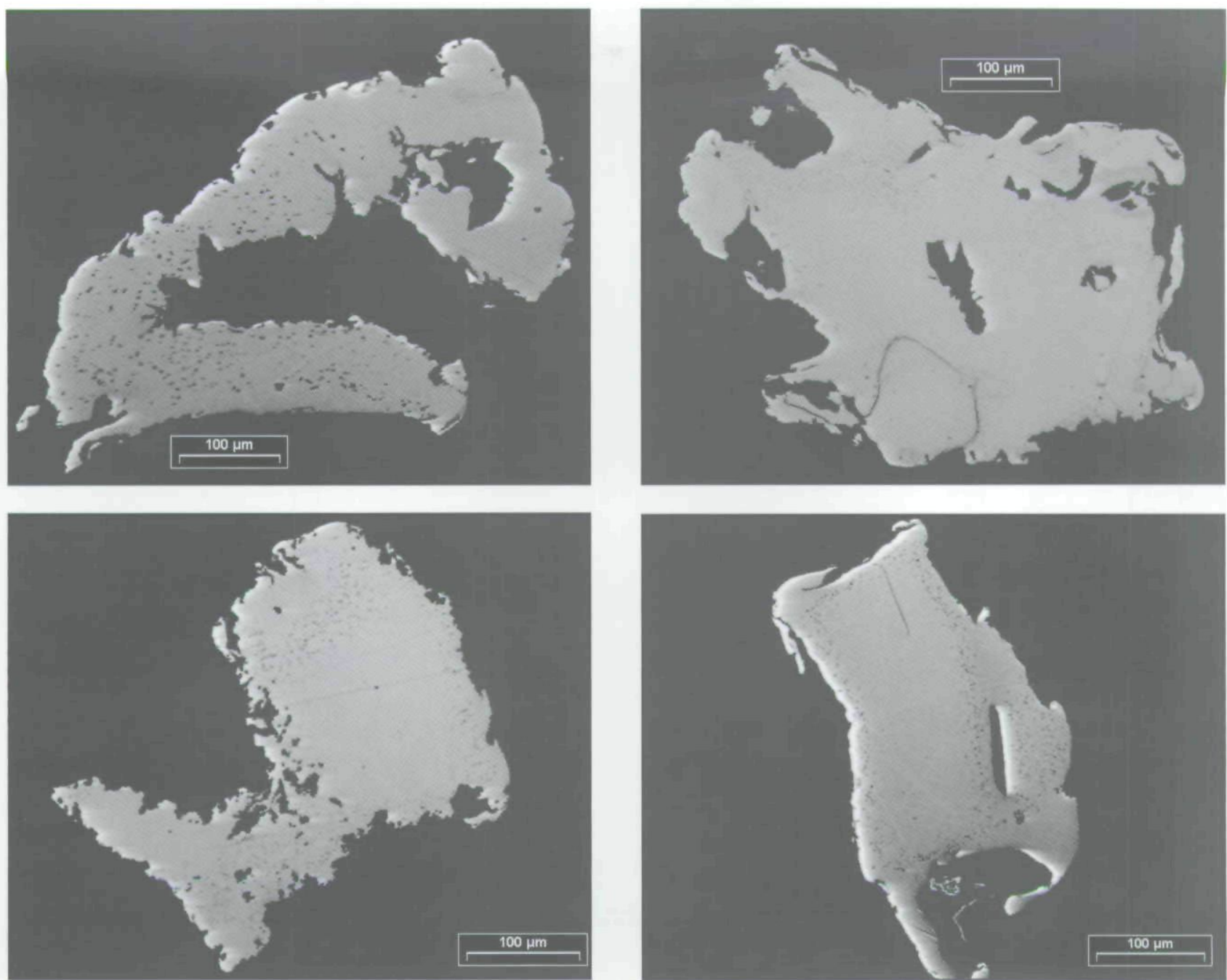

Figure 3. Backscatter electron images of gold-rich alloy from Merensky Reef concentrate. Dark inclusions of PGM (with lower average density than gold) define distinct zones.

\section{Observations}

\section{The metallic gold bost}

Our study confirms the compositions of the gold-rich alloys reported previously (Schwellnus et al., 1976; Kingston and El-Dosuky, 1982). The gold analyses in our study were performed in areas of the gold grains which did not contain visible inclusions. It appears that a small proportion of these grains are very pure gold with $\sim 86$ to 92 atomic $\% \mathrm{Au}$, while the majority contains substantial amounts of $\mathrm{Ag}$ with 74 to 44 atomic \% Au (Figure 1). Many of the more Ag-rich alloys contain up to $\sim 9$ atomic \% Pd ( 6 weight \% Pd) in solid solution (Figure 2).

\section{The inclusions}

Not all gold grains contain visible inclusions. However, it is not clear whether the lack of inclusions is a function of the grain exposure. Most grains have areas that are free of inclusions, with the highest density of inclusions in specific zones or rims of the gold grains (Figure 3).

Most of the inclusions in the gold-rich alloys are round to lenticular with the largest axis commonly below $2 \mu \mathrm{m}$, with a median of $1.85 \mu \mathrm{m}$ for 430 inclusions (Figure 4). It is sometimes possible to microscopically distinguish more than one type of inclusion in a particular gold-rich alloy grain, but the small grain sizes make an identification impossible. Therefore, these inclusions can only be distinguished and identified based on their element combinations.

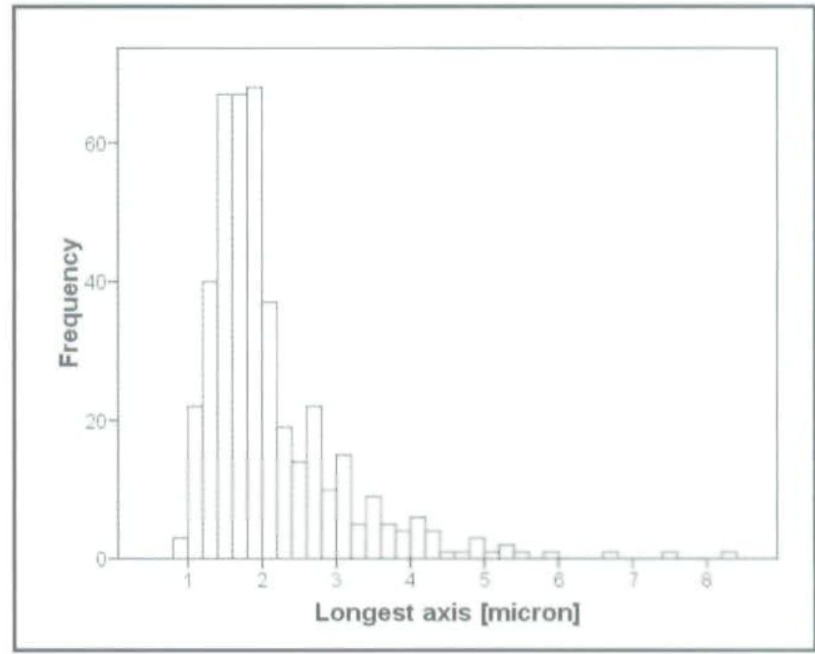

Figure 4. Size distribution of 430 inclusions in gold-rich alloy. Arithmetic mean 2. 11 micron; median 1. 85 micron 
Table 1. Selected analyses in wt.-\% of inclusions in gold-rich alloys to demonstrate the mixed character of analyses of atokite $\left((\mathrm{Pd}, \mathrm{Pt})_{3} \mathrm{Sn}\right)$ and paolovite $\left((\mathrm{Pd}, \mathrm{Pt})_{2} \mathrm{Sn}\right)$

\begin{tabular}{lcrrrrr}
\hline Pd & Pt & Sn & \multicolumn{1}{c}{ Au } & Ag & Total & Mineral \\
\hline 38.76 & & 13.22 & 39.30 & 9.16 & 100.44 & atokite \\
31.64 & & 10.25 & 46.95 & 12.00 & 100.84 & atokite \\
54.05 & & 18.93 & 19.69 & 7.67 & 100.34 & atokite \\
42.18 & & 14.07 & 35.77 & 8.69 & 100.71 & atokite \\
33.26 & & 12.06 & 40.56 & 12.51 & 98.39 & atokite \\
39.84 & & 13.98 & 36.52 & 9.18 & 99.52 & atokite \\
45.52 & & 23.26 & 25.05 & 7.28 & 101.11 & paolovite \\
63.04 & 2.48 & 35.16 & 3.18 & & 103.86 & paolovite \\
55.75 & 3.77 & 30.81 & 9.17 & 1.23 & 100.73 & paolovite \\
59.07 & 1.81 & 32.99 & 6.71 & & 100.58 & paolovite \\
60.58 & 2.25 & 34.77 & 2.02 & & 99.62 & paolovite \\
23.64 & & 11.59 & 40.76 & 24.03 & 100.02 & paolovite \\
42.93 & & 19.84 & 31.14 & 8.14 & 102.05 & paolovite \\
40.05 & & 20.44 & 32.29 & 9.18 & 101.96 & paolovite \\
45.35 & & 22.54 & 27.90 & 5.08 & 100.87 & paolovite \\
\hline
\end{tabular}

Quantitative microprobe analyses are hampered by interference from the surrounding gold-rich alloys. Although many analyses resulted in totals close to 100 weight $\%$ (Table 1) and imply element proportions close to expected stoichiometries, the high proportions of $\mathrm{Au}$ and $\mathrm{Ag}$ render these analyses only semi-quantitative.
Table 2. Platinum-group minerals identified as inclusions in goldrich alloys ${ }^{\circ}=$ not observed in this study

\begin{tabular}{ll}
\hline Platinum-group mineral & Formula \\
\hline atokite & $(\mathrm{Pd}, \mathrm{Pt})_{3} \mathrm{Sn}$ \\
kotulskite & $\mathrm{Pd}(\mathrm{Te}, \mathrm{Bi})$ \\
laurite & $\mathrm{RuS}_{2}$ \\
mertiite II & $\mathrm{Pd}_{8} \mathrm{Sb}_{3}$ \\
moncheite & $(\mathrm{Pt}, \mathrm{Pd})(\mathrm{Te}, \mathrm{Bi})_{2}$ \\
niggliite & $(\mathrm{Pt}, \mathrm{Pd}) \mathrm{Sn}$ \\
paolovite & $(\mathrm{Pd}, \mathrm{Pt})_{2} \mathrm{Sn}$ \\
rustenburgite & $(\mathrm{Pt}, \mathrm{Pd})_{3} \mathrm{Sn}$ \\
sobolevskite & $\mathrm{Pd}_{1-1.1} \mathrm{Bi}$ \\
sperrylite & $\mathrm{PtAs}_{2}$ \\
\hline
\end{tabular}

Based on their element combinations and proportions, a wide range of inclusions were recognized (Table 2). The most common inclusions contain Pd or Pt and Sn. Our observations imply that in the Merensky Reef, Pd-rich inclusions vastly outnumber the Pt-rich inclusions. Niggliite, (Pt,Pd)Sn, is a rare mineral, while paolovite ((Pd,Pt $)_{2} \mathrm{Sn}$ with variable but low $\mathrm{Pt}$ content) and atokite $\left((\mathrm{Pd}, \mathrm{Pt})_{3} \mathrm{Sn}\right.$ without detectable $\left.\mathrm{Pt}\right)$ are the most common inclusions. Rustenburgite, $(\mathrm{Pt}, \mathrm{Pd})_{3} \mathrm{Sn}$, inclusions were encountered only rarely, but their composition appears to fall inside the range of $\mathrm{Pt} / \mathrm{Pd}$

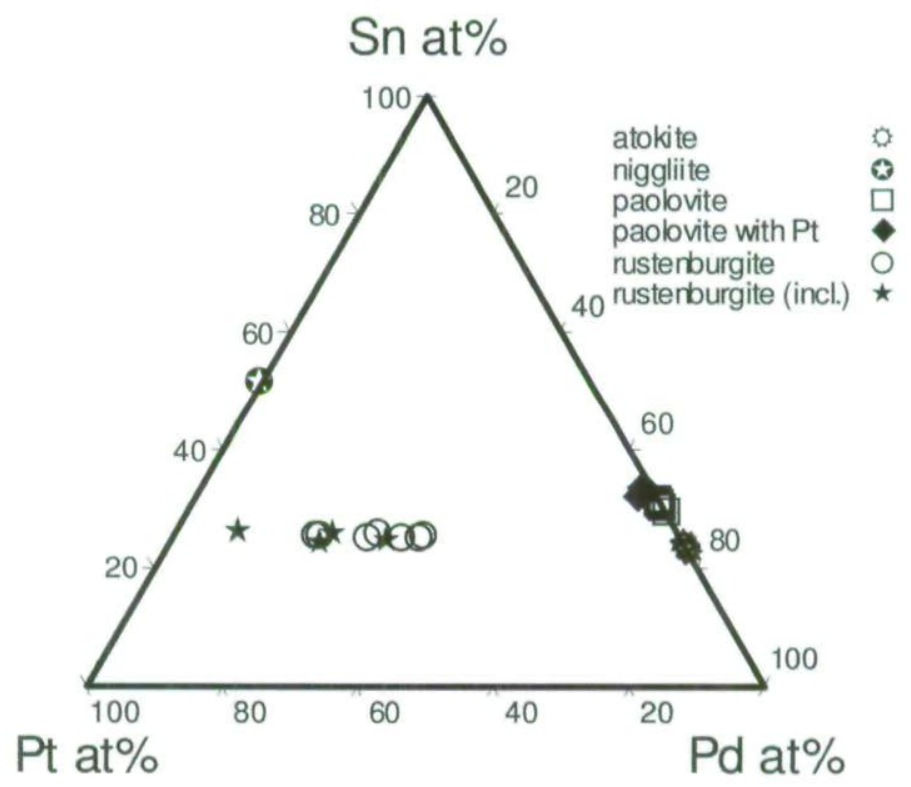

Figure 5. Compositional variation of Pt-Pd-Sn phases. Rustenburgite, (Pt,Pd) 3 Sn, attached to gold (open circle) shows compositional overlap with rustenburgite inclusions in gold (stars). 


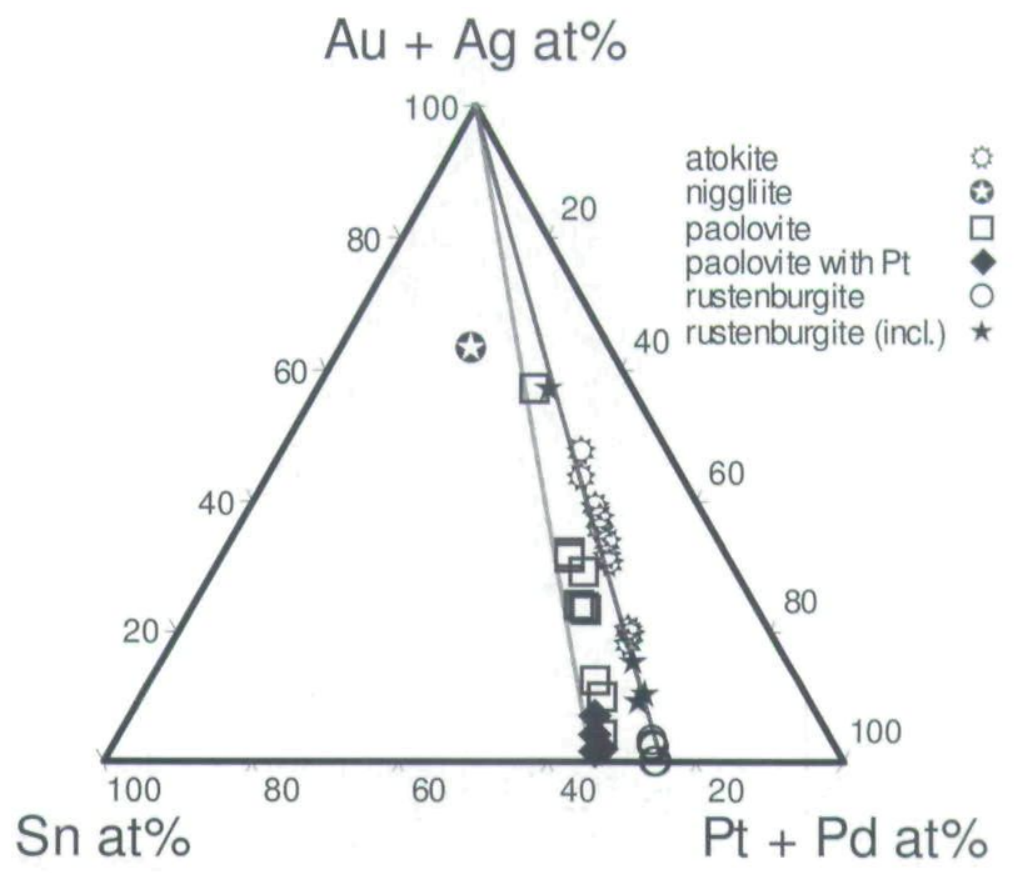

Figure 6. Distinction between paolovite, $(\mathrm{Pd}, \mathrm{Pt})_{2} \mathrm{Sn}$, and atokite / rustenburgite, $(\mathrm{Pd}, \mathrm{Pt})_{3} \mathrm{Sn}$, despite interference from gold-rich alloy.

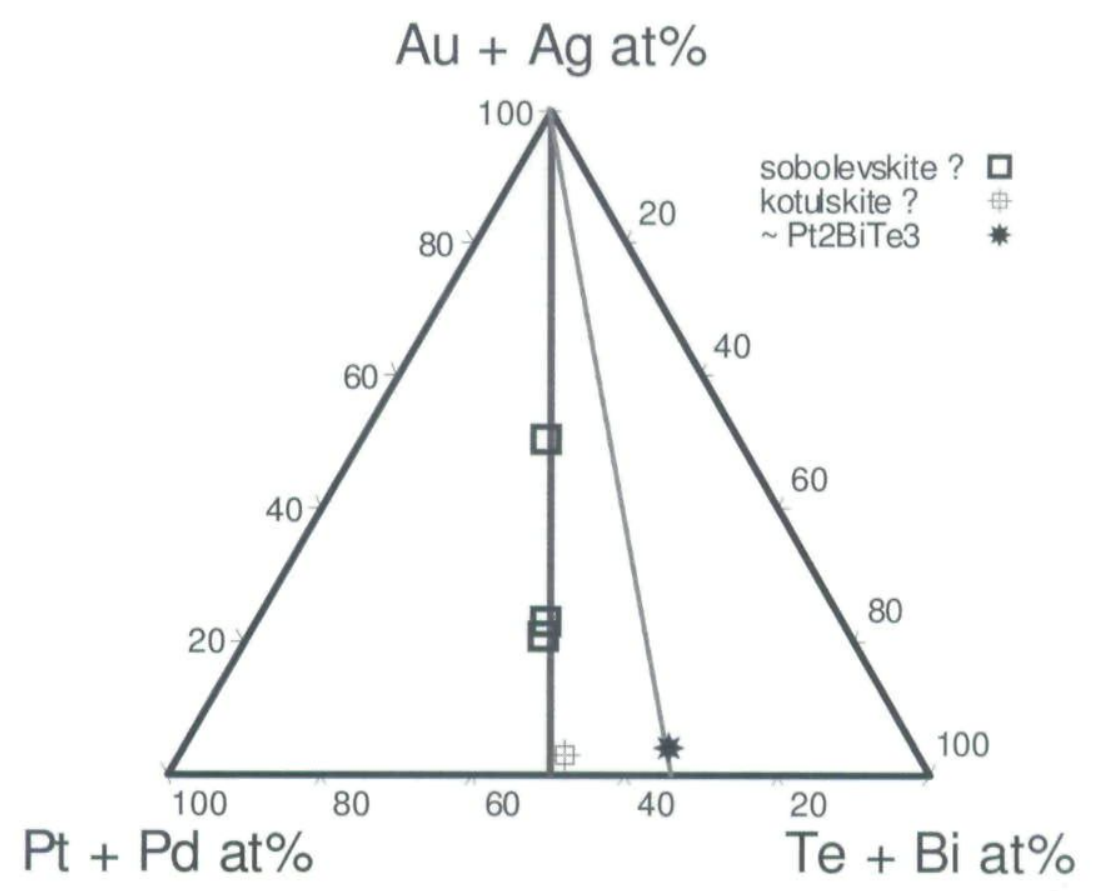

Figure 7. $(\mathrm{Pt}+\mathrm{Pd}) /(\mathrm{Te}+\mathrm{Bi})$ ratios of some inclusions. 


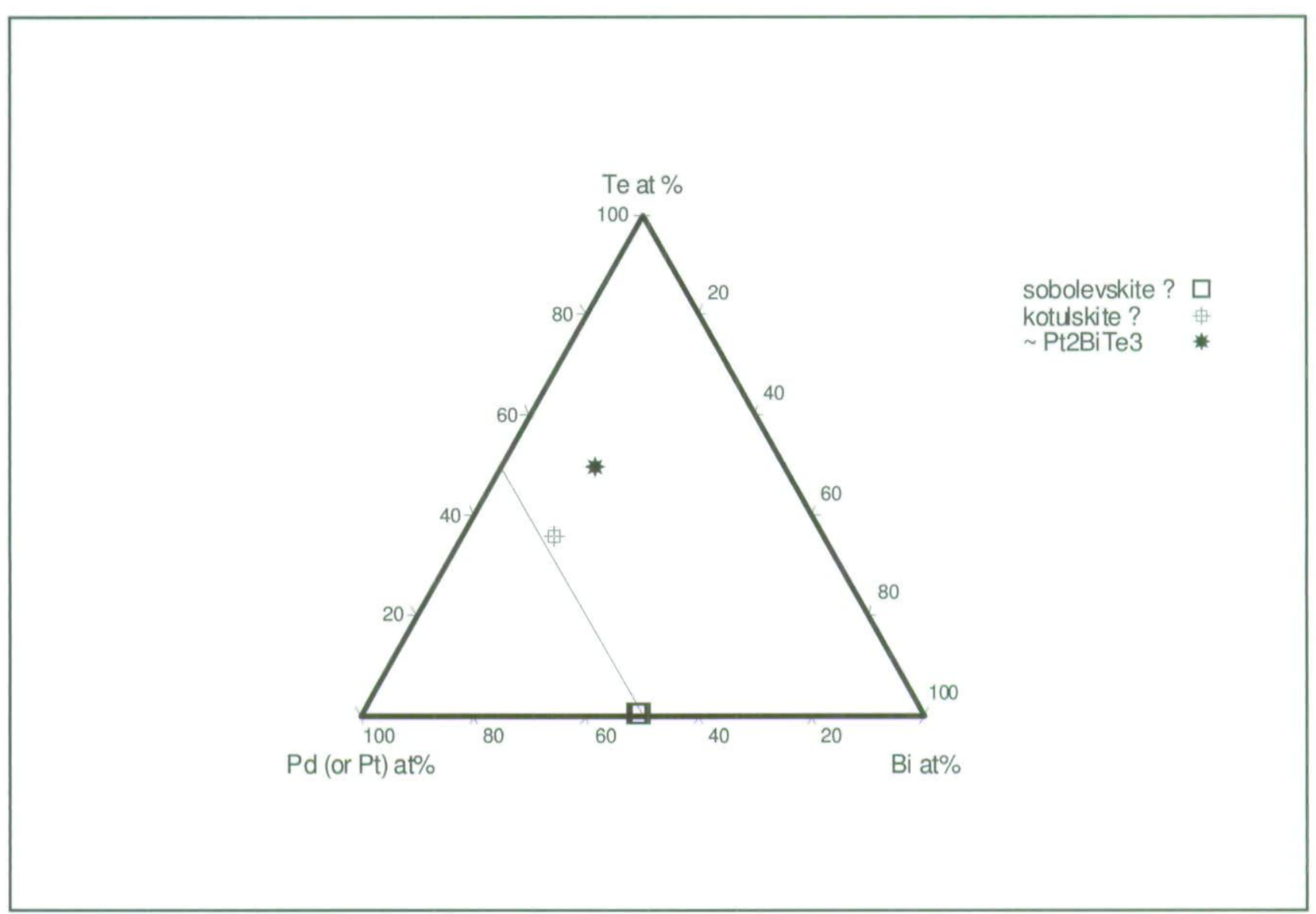

Figure 8. Analyses of kotulskite, $\mathrm{Pd}(\mathrm{Te}, \mathrm{Bi})$, should plot on the line of 50 at $\% \mathrm{Pd}$.

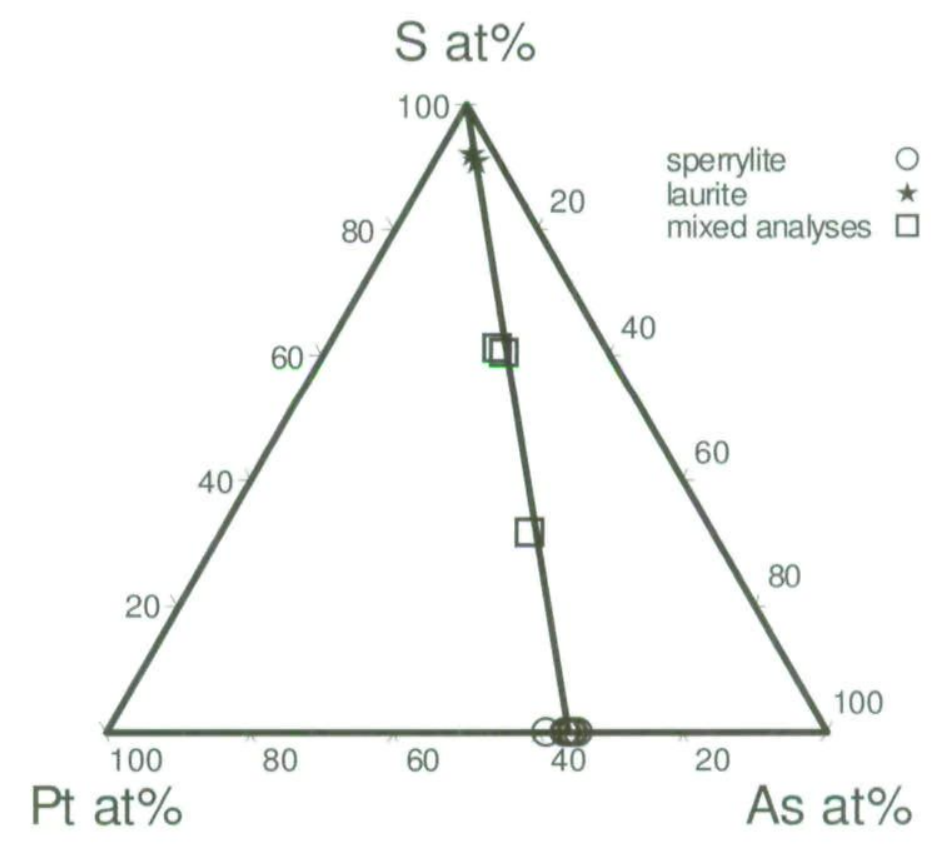

Figure 9. Analyses representing sperrylite, laurite, and mixed analyses between the two. 


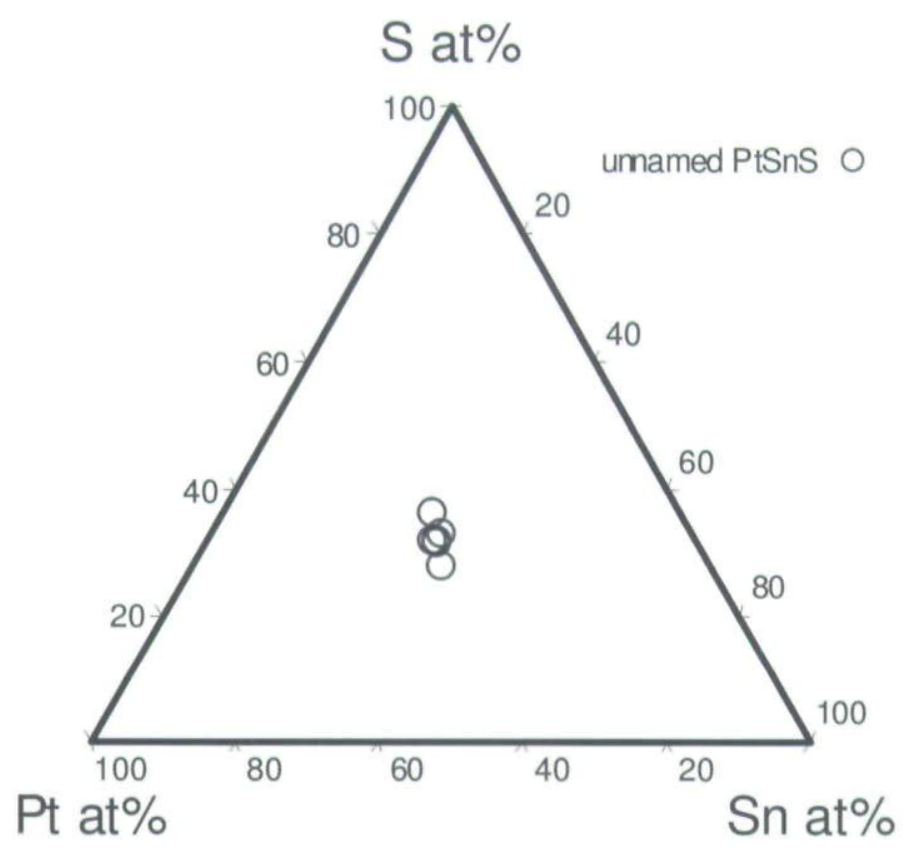

Figure 10. Projection of six analyses of unnamed PtSnS.

ratios of rustenburgite attached to the gold-rich alloys (Figure 5). The ratio of $\mathrm{Sn}$ to $(\mathrm{Pd}+\mathrm{Pt})$ of atokite and rustenburgite seems not to be vastly affected by the amount of interference from surrounding gold-rich alloy, while most analyses of paolovite deviate from the expected ratio by a surplus of $(\mathrm{Pd}+\mathrm{Pt}$ ) (Figure 6). An isothermal section of the system Au-Pd-Sn at room temperature (Anhock et al., 1998) implies that synthetic $\mathrm{Pd}_{2} \mathrm{Sn}$ (equivalent to the natural paolovite) can exhibit an extensive range of solid solution with up to ca 15 atomic $\% \mathrm{Au}$, if coexisting with a gold-rich alloy. Most of our mixed analyses (Table 1) calculate to $(\mathrm{Pd}, \mathrm{Pt})_{2+\mathrm{x}} \mathrm{Sn}$ and give no indication of $\mathrm{Au}$ substituting for $\mathrm{Pd}$ in this paolovite. A surplus of $\mathrm{Pt}+\mathrm{Pd}$ appears to be a common feature of paolovite (Cabri, 2002).

In some grains, inclusions containing $\mathrm{Te}$ and $\mathrm{Bi}$ were encountered (Figure 7). There is little doubt about the identity of sobolevskite $\left(\mathrm{Pd}_{1-1.1} \mathrm{Bi}\right)$, but the analysis which we interpret to be kotulskite, $\mathrm{Pd}(\mathrm{Te}, \mathrm{Bi})$, seems to be slightly Pd-deficient (Figure 8). We attribute this to analytical problems. The third type of inclusion in Figures 7 and 8 appears to be moncheite (general formula $(\mathrm{Pt}, \mathrm{Pd})(\mathrm{Te}, \mathrm{Bi})_{2}$, but in this case no $\mathrm{Pd}$ was found), although the composition is very close to $\mathrm{Pt}_{2} \mathrm{BiTe}_{3}$ and may suggest a distinct phase. Too little information is available to warrant speculation.

Sperrylite $\left(\mathrm{PtAs}_{2}\right)$ and laurite $\left(\mathrm{RuS}_{2}\right)$ were found as isolated and small combined inclusions, which resulted in some mixed analyses (Figure 9).
Not all analyzed inclusions could be allocated to known PGM. Even if severe analytical problems are assumed, some grains appear to represent unnamed minerals. We observed three grains consisting of Pd, Sn, and As, but were not able to obtain acceptable analyses. The analysis with the highest total of 93.5 weight \% calculates to $\sim \mathrm{Pd}_{7.8} \mathrm{Sn}_{2} \mathrm{As}$.

Several grains of a phase containing only $\mathrm{Pt}, \mathrm{Sn}$, and S were encountered (Figure 10). Although all analyses have low totals and are considered semi-quantitative, there is little doubt that the composition of this phase is PtSnS.

We did not observe any inclusions containing Sb and can therefore not confirm the presence of inclusions which may be considered to be mertieite II $\left(\mathrm{Pd}_{8} \mathrm{Sb}_{3}\right)$.

\section{Discussion \\ Mineralogy}

There are clearly similarities between the compositions of the gold found in our study and the analyses reported previously from the Merensky Reef. Gold from Atok appears to contain small amounts of Pt instead of Pd (Schwellnus et al., 1976), while none of our analyses of inclusion-free gold contained platinum in detectable amounts. We are inclined to believe that tiny inclusions of Pt-containing minerals may be responsible and that the reported Pt is not present as a solid solution in gold.

Palladian gold has been reported from many localities. Judging from the available literature it seems 
that even grains with $\sim 12$ weight $\% \mathrm{Pd}$ from the Miessijoki placer in Finland (Törnroos and Vuorelainen, 1987), or up to 19 weight \% Pd in the Cauê Mine in Brasil (Olivo et al., 1994; Olivo et al., 1995) are homogeneous. However, this aspect will require careful re-evaluation because palladian gold from Cauê Mine certainly can be compositionally and mineralogically heterogeneous (J.H.D. Schorscher, personal communication, 2004). The gold from the Merensky Reef, with a considerable lower Pd-content of up to about 6 weight $\%$, undeniably has $\mathrm{Pd}$ in solid solution and contains particulate Pd-rich phases as inclusions.

Although inclusions of platinum-group minerals in gold-rich alloys are rarely reported, the observation of such a case in the alluvium of the Durance River, France (Johan et al., 1990), where the gold contains $\sim 2 \mu \mathrm{m}$ sized inclusions enriched in $\mathrm{Ni}, \mathrm{Pt}$ and $\mathrm{Sn}$ and up to $\sim 3$ weight $\%$ of $\mathrm{Sn}$, shows that the Merensky Reef is not unique and that a systematic search for such inclusions might reveal more examples.

Unfortunately, the gold grains in this study are isolated from their original setting and it is therefore not possible to relate the dominance of specific minerals observed as inclusions (i.e., platinum group minerals containing $\mathrm{Bi}, \mathrm{Te}, \mathrm{Sn}$, and $\mathrm{As}$ ) in a gold grain to the proportions of platinum-group minerals in the mineral assemblage in a given locality (Kinloch, 1982).

The unnamed Pt-Sn-S phase is occasionally encountered in very small grains in the UG-2, the Platreef, and the Merensky Reef (Kinloch, 1982; Louwrens, 1996), but normally grain sizes are too small to obtain quantitative information about the proportions of the elements. The only quantitative analyses in the available literature (Barkov et al., 2001) show very little variation in the composition compared to our analyses. Whether this is purely an analytical artefact remains unresolved.

\section{Genesis}

The "hydrothermal" concept for the formation of the Merensky Reef has been advocated by some scientists, i.e., that the Merensky Reef is a mineralization in which the PGE were remobilised, if not introduced, by fluids (Stumpfl and Tarkian, 1976; Ballhaus and Stumpfl, 1986; Barnes and Campbell, 1988). Evidence for the hydrothermal modification of platinum group minerals in the Merensky Reef has been presented (Merkle and Verryn, 2003). The formation of metallic gold grains of the sizes which form the bulk of this investigation is very unlikely if only magmatic processes are considered.

The tenor of 2 to 3 weight $\%$ base metal sulphides (Merkle and McKenzie, 2002) in the Merensky Reef is thought to have accumulated under magmatic conditions as a sulphide melt (Naldrett et al., 1986; Barnes and Campbell, 1988; Cawthorn and Boerst, 2006; Wilson and Chunnett, 2006). The partition coefficient of $\mathrm{Au}$ into such sulphide melts (i.e., the ratio of the concentration in the sulphide melt divided by the concentration in the silicate melt under equilibrium conditions) has been estimated to be up to 18600 (Peach et al., 1990; Stone et al., 1990), depending on intrinsic conditions like oxygen fugacity, cation ratios in the sulphide melt, or metal/sulphur ratio of the sulphide melt (Crocket et al., 1992; 1997; Fleet et al., 1999). Such high partition coefficients suggest that the element in question is homogeneously distributed throughout the sulphide melt.

Gold is alloyed with variable amounts of silver, copper, and other minor components (like Pd) in a metallic phase of very high density, whereas most of the PGE form compounds (with sulphur, tellurium, and other ligands) of lower density. A variable proportion of $\mathrm{Pd}$ is present as solid solution in base metal sulphides (Paktunc et al., 1990; Cabri, 1992; Ballhaus and Ryan, 1995) and except for selected localities, Pt-Fe alloys are rare (Kinloch, 1982), i.e., the volume proportion of metallic gold should be considerably lower than the weight proportion (1.5 to $6.6 \%$ of $\sum \mathrm{PGE}+\mathrm{Au}$ ) suggests. It is also to be expected that the bulk of the low gold concentration in the sulphide melt would result in small, finely dispersed grains on cooling. Reports of higher proportions of metallic gold in Merensky Reef (Kinloch, 1982) therefore imply remobilisation and concentration of metallic gold. Large grains of up to $500 \mu \mathrm{m}$ length as studied here are therefore considered to have formed by hydrothermal remobilisation from magmatic sulphides and the co-precipitation of the gold and its inclusions.

Individual grains contain distinct zones in which the dusting of PGM occurs. In our opinion these zones represent growth zones of the gold. Our observations imply that in the coarse gold from the Merensky Reef, Pd-rich inclusions vastly outnumber the presence of Pt-rich inclusions.

If these inclusions of PGM represent exsolutions, this would imply that the high temperature alloy contained a higher amount of Pd in solid solution, which exceeded solubility on cooling, while the concentration of Pt was lower and was more efficiently exsolved. It also would imply that the $\mathrm{Sn}, \mathrm{Bi}$, and $\mathrm{Te}$ in the PGM had to be dissolved in the gold as well. We were not successful in our attempts to locate phase diagrams which would allow us to quantify the maximum solubility of $\mathrm{Sn}, \mathrm{Bi}$, and $\mathrm{Te}$ in gold as a function of temperature under hydrothermal conditions. However, phase diagrams of binary systems relevant to our study show that there is an extended solid solution between $\mathrm{Au}$ and $\mathrm{Pd}, \mathrm{Pt}$, or Sn at elevated temperatures, by far exceeding the values observed in the gold grains under investigation (Massalski, 1990), although solubility might be reduced at low temperature. There is no indication that the solubility of Pt in gold is so distinctly lower than of Pd at the concentration levels in this gold that it could cause the observed dominance of Pd-rich PGM. This implies that the element content of the inclusions are unlikely to have been in solid solution and unmixed on cooling. The finely dispersed PGM in gold-rich alloys are 
therefore considered to be physical inclusions, not exsolutions, and the additional presence of $\mathrm{Sn}, \mathrm{Bi}, \mathrm{Te}$, and As in the fluid must be seen as the reason for the presence of particulate PGM.

The palladium dominance must therefore be a function of the composition of the hydrothermal fluid from which the gold precipitated.

The differences in the aqueous geochemistry of $\mathrm{Pt}$ and Pd are small but distinct enough to cause a smaller stability field of PdS (vysotskite) compared to PtS (cooperite), depending on temperature, $\mathrm{pH}$, chlorine activity, and oxygen fugacity (Wood et al., 1992; Gammons et al., 1992). It is therefore possible to preferentially leach $\mathrm{Pd}$ from ( $\mathrm{Pd}, \mathrm{Pt}, \mathrm{Ni}) \mathrm{S}$ (braggite). This is the reason why braggite, the most likely primary PGM forming from the sulphide melt, may loose Pd preferentially through interaction with hydrothermal fluids (Merkle and Verryn, 2003). Examples for such Pd-depleted braggite are known, amongst others, from the Merensky Reef (Schwellnus et al., 1976; Cabri et al., 1978; Kingston and El-Dosuky, 1982; Mostert et al., 1982) and Lukkulaisvaara (Barkov et al., 1995).

The precipitation of PGM and inclusion in the gold grains would have to happen below the upper thermal stability limits of the inclusions. Unfortunately, the upper thermal stability limits for all the minerals found as inclusions are rather high. Kotulskite has a minimum stability temperature of $720^{\circ} \mathrm{C}$ (Elliot, 1965; Shunk, 1969), while atokite, moncheite, niggliite, and rustenburgite were synthesized at $1000^{\circ} \mathrm{C}$ (Shelton et al., 1981; Kim, 1990). Laurite and sperrylite can be found as primary inclusions in chromite grains, which imply even higher stability temperatures. All the phases that occur as inclusions in gold, and for which thermal stability could be obtained, are stable at temperatures which are to the high end of temperatures expected for any hydrothermal activity that may have redeposited gold.

\section{Summary and Conclusions}

We conclude that the assemblage of inclusions in the large gold-rich alloys of the Merensky Reef reflects the variability of compositions and intrinsic conditions of hydrothermal fluids, which occasionally remobilised and precipitated $\mathrm{Au}$ and $\mathrm{Ag}$ in the Merensky Reef into large grains. The rarity of these large gold-rich alloy grains implies that the bulk of the low Au concentration is finely dispersed in small grains. Inclusions of PGM are interpreted to be co-precipitates from the same hydrothermal fluids, It is at present not possible to quantify the conditions under which these gold grains were precipitated.

\section{Acknowledgments}

We were requested to keep the source of the material confidential, which does not diminish our gratitude for the opportunity to report on our findings. We thank Louis Cabri and the anonymous reviewers for their constructive comments.

\section{References}

Anhock, S., Oppermann, H., Kallmayer, C., Aschenbrenner, R., Thomas, L. and Reichl, H. (1998), in Investigations of Au-Sn alloys on different endmetallizations for high temperature applications. In: Electronics Manufacturing Technology Symposium, 1998. IEMT-Europe 1998. TwentySecond IEEE/CPMT International, 156-165.

Ballhaus, C. and Ryan, C.G. (1995). Platinum-group elements in the Merensky Reef I. PGE in solid solution in base metal sulphides and the down-temperature equilibrium history of Merensky ores. Contributions to Mineralogy and Petrology, 122, 122-241.

Ballhaus, C.G. and Stumpfl, E.F. (1986). Sulfide and platinum mineralisation in the Merensky Reef: evidence from hydrous silicates and fluid inclusions. Contributions to Mineralogy and Petrology, 94, 193-204.

Barkov, A.Y., Martin, R.F., Kaukonen, R.J. and Alapieti, T.T. (2001). The occurrence of $\mathrm{Pb}-\mathrm{Cl}-(\mathrm{OH})$ and $\mathrm{Pt}-\mathrm{Sn}-\mathrm{S}$ compounds in the Merensky Reef, Bushveld layered complex, South Africa. Canadian Mineralogist, 39, 1397-1403.

Barkov, A.Y., Pakhomovskii, Y.A. and Menshikov, Y.P. (1995). Zoning in the platinum-group sulfide minerals from the Lukkulaisvaara and Imandrovsky layered intrusions, Russia. Neues Jabrbuch für Mineralogie, Abhandlungen, $169,97-117$

Barnes, S.J. and Campbell, I.H. (1988). Role of late magmatic fluids in Merensky-type platinum deposits: a discussion. Geology, 16, 488-491.

Barnes, S.-J. and Maier, W.D. (2002). Platinum-group Elements and Microstructures of Normal Merensky Reef from Impala Platinum Mines, Bushveld Complex. Journal of Petrology, 43, 103-128.

Brynard, H.J., De Villiers, J.P.R. and Viljoen, E.A. (1976). A mineralogical investigation of the Merensky Reef at the Western Platinum Mine, near Marikana, South Africa. Economic Geology, 71, 1299-1307.

Cabri, L.J. (1980). Determination of ideal formulae for new minerals of the platinum group. In: A.V. Sidorenko, V.S. Sobolev, D.V. Rundquist, I.Y. Nekrasov, T.N. Shadlun, A.D. Genkin, N.N. Mozgova and N.S. Bortnikov (Editors), Sulphosalts, Platinum Minerals and Ore Microscopy. Proceedings of the XI.tb General Meeting of the International Mineralogical Association, Novosibirsk, 1978. Institute of the Geology of Ore Deposits, Akad. Nauk SSSR, Nauka, Moscow, USSR, 157-165.

Cabri, L.J. (1992). The distribution of trace precious metals in minerals and mineral products. Mineralogical Magazine, 56, 289-308.

Cabri, LJ. (2002). The Platinum-Group Minerals, In: LJ. Cabri (Editor), The Geology, Geochemistry, Mineralogy and Mineral Beneficiation of Platinum-Group Elements. Canadian Institute of Mining, Metallurgy and Petroleum, Special Volume, 54, 13-129.

Cabri, L.J., Laflamme, J.H.G., Stewart, J.M., Turner, K. and Skinner, B.J. (1978). On cooperite, braggite and vysotskite. American Mineralogist, 63, 832-839

Cawthorn, R.G. and Boerst, K. (2006). Origin of the pegmatitic pyroxenite in the Merensky Unit, Bushveld Complex, South Africa. Journal of Petrology, 47, 1509-1530

Crocket, J.H., Fleet, M.E. and Stone, W.E. (1992). Experimental partitioning of osmium, iridium and gold between basalt melt and sulphide liquid at $1300^{\circ} \mathrm{C}$. Australian Journal of Earth Science, 39, 427-432.

Crocket, J.H., Fleet, M.E. and Stone, W.E. (1997). Implications of composition for experimental partitioning of platinum-group elements and gold between sulfide liquid and basalt melt: The significance of nickel content. Geochimica et Cosmochimica Acta, 61, 4139-4149.

Elliot, R.P. (1965) Constitution of Binary Alloys. 1st Supplement. McGrawHill, New York, 877p.

Farquhar, J. (1986). The Western Platinum Mine. In: C.R. Anhaeusser and S. Maske (Editors), Mineral Deposits of Southern Africa. Geological Society of South Africa, 1135-1142.

Fleet, M.E., Crocket, J.H., Liu, M. and Stone, W.E. (1999). Laboratory partitioning of platinum-group elements (PGE) and gold with application to magmatic sulfide-PGE deposits. Litbos, $\mathbf{4 7 , 1 2 7 - 1 4 2 .}$

Franklyn, C.B. and Merkle, R.K.W. (1999). Milli-PIXE of coexisting cooperite and braggite - a comparison with electron microprobe analysis. Nuclear Instruments and Methods in Pbysics Research B, 158, 550-555.

Gammons, C.H., Bloom, M.S., and Yu, Y. (1992). Experimental investigation of the hydrothermal geochemistry of platinum and palladium: I. Solubility of platinum and palladium sulfide minerals in $\mathrm{NaCl} / \mathrm{H}_{2} \mathrm{SO}_{4}$ solutions at $300^{\circ} \mathrm{C}$. Geochimica et Cosmochimica Acta, 56, 3881-3894. 
Johan, Z., Ohnenstetter, M., Fischer, W., and Amossé, J. (1990). Platinumgroup minerals from the Durance River alluvium, France, Mineralogy and Petrology, 42, 287-306.

Kim, W.S. (1990), Phase relations in the system Pt-Sb-Te. Canadian Mineralogist, 28, 675-685.

Kingston, G.A. and El-Dosuky, B.T. (1982), A contribution on the platinumgroup mineralogy of the Merensky Reef at the Rustenburg platinum mine. Economic Geology, 77, 1367-1384.

Kinloch, E.D. (1982). Regional trends in the platinum-group mineralogy of the Critical Zone of the Bushveld Complex, South Africa. Economic Geology, 77, 1328-1347

Leeb-Du Toit, A. (1986). The Impala Platinum Mines. In: C.R. Anhaeusser and S. Maske (Editors), Mineral Deposits of Southern Africa. Geological Society of South Africa, 1091-1106.

Louwrens, E.L. (1996). Mineralogical investigations of platinum-group minerals in UG-2 plant products (U101; U102). Confidential Report. R55/96-IMR.27. Impala Platinum. 23 p.

Massalski, T.B. (Editor) (1990). Binary alloy phase diagrams. American Society for Metals, Metals Park, Obio, United States of America, 2224p.

Merkle, R.K.W. and McKenzie, A.D. (2002). The Mining and Beneficiation of South African PGE Ores - An overview. In: L.J. Cabri (Editor), The Geology, Geochemistry, Mineralogy and Mineral Beneficiation of Platinum-Group Elements. Canadian Institute of Mining, Metallurgy and Petroleum, Special Volume, 54, 793-809.

Merkle, R.K.W. and Verryn, S.M.C. (1991). Coexisting cooperite and braggite - new data. ICAM '91, International Congress on Applied Mineralogy Papers. Mineralogical Association of South Africa, 2 Chapter 61, 1-16.

Merkle, R.K.W. and Verryn, S.M.C. (2003). Cooperite and braggite from the Bushveld Complex: implications for the miscibility gap and identification. Mineralium Deposita, 38, 381-388.

Mihálik, P., Hiemstra, S.A., and De Villiers, J.P.R. (1975). Rustenburgite and atokite, two new platinum-group minerals from the Merensky Reef, Bushveld igneous complex. Canadian Mineralogist, 146-150.

Mossom, R.J. (1986). The Atok Platinum Mine. In: C.R. Anhaeusser and S. Maske (Editors), Mineral Deposits of Southern Africa. Geological Society of South Africa, 1143-1154.

Mostert, A.B., Hofmeyr, P.K. and Potgieter, G.A. (1982). The platinum group mineralogy of the Merensky Reef at the Impala platinum mines, Bophuthatswana. Economic Geology, 77, 1385-1394

Naldrett, A.J., Gasparrini, E.C., Barnes, S.J., Von Gruenewaldt, G. and Sharpe, M.R. (1986). The upper critical zone of the Bushveld Complex and a model for the origin of Merensky-type ores. Economic Geology. 81, 1105-1117.

Oberthür, T., Melcher, F., Gast, L., Wöhrl, C., and Lodziak, J. (2004). Detrital platinum-group minerals in rivers draining the eastern Bushveld Complex South Africa. Canadian Mineralogist, 42, 563-582.

Olivo, G.R., Gauthier, M. and Bardoux, M. (1994). Palladian gold from the Caue iron mine, Itabira District, Minas Gerais, Brazil. Mineralogical Magazine, 58, 579-587.

Olivo, G.R., Gauthier, M., Bardoux, M., Desa, E.L., Fonseca, J.T.F. and Santana, F.C. (1995). Palladium-bearing gold deposit hosted by Proterozoic lake superior-type iron-formation at the Caue iron mine, Itabira district, southern Sao Francisco craton, Brazil: Geologic and structural controls. Economic Geology, 90, 118-134.

Paktunc, A.D., Hulbert, L.J. and Harris, D.C. (1990). Partitioning of the platinum-group and other trace elements in sulfides from the Bushveld Complex and Canadian occurrences of Nickel-Copper sulfides. Canadian Mineralogist, 28, 475-488.

Peach, C.L., Mathez, E.A. and Keays, R.R. (1990). Sulfide melt - silicate melt distribution coefficients for noble metals and other chalcophile elements as deduced from MORB: implications for partial melting. Geochimica et Cosmocbimica Acta, 54, 3379-3389.
Reed, S.J.B. (1975) Electron Microprobe Analysis, 1 Edition, Cambridge University Press, United Kingdom, 400p.

Reid, A.M., Le Roex, A.P. and Minter, W.E.L. (1988). Composition of gold grains in the Vaal Placer, Klerksdorp, South Africa. Mineralium Deposita. 23, 211-217.

Schwellnus, J.S.J., Hiemstra, S.A. and Gasparrini, E. (1976). The Merensky reef at the Atok platinum mine and its environs. Economic Geology. 71, 249-260.

Shelton, K.L., Merewether, P.A., and Skinner, B.J. (1981). Phases and phase relations in the system Pd-Pt-Sn. Canadian Mineralogist, 19, 599-605.

Shunk, F.A. (1969). Constitution of Binary Alloys. 2nd Supplement, McGrawHill, New York, 720 p.

Steele, T.W., Levin J., and Copelowitz, I. (1975). The preparation and certification of a reference sample of a precious metal ore. NIM Report. 1696, $50 \mathrm{p}$.

Stone, W.E., Crocket, J.H., and Fleet, M.E. (1990). Partitioning of palladium. iridium, platinum, and gold between sulfide liquid and basalt melt at $1200^{\circ} \mathrm{C}$. Geochimica et Cosmochimica Acta, 54, 2341-2344.

Stumpfl, E.F. and Tarkian, M. (1976). Platinum genesis: New mineralogical evidence. Economic Geology, 71, 1451-1460.

Törnroos, R. and Vuorelainen,Y. (1987). Platinum-group metals and their alloys in nuggets from alluvial deposits in Finnish Lapland. Lithos, 20, 491-500.

Vermaak, C.F. (1976). The Merensky Reef - thoughts on its environment and genesis. . Economic Geology, 71, 1270-1298.

Vermaak, C.F and Hendriks, L.P. (1976). A review of the mineralogy of the Merensky Reef, with specific reference to new data on precious metal mineralogy. Economic Geology, 71, 1244-1269.

Viljoen, M.J. (1994). A review of regional variations in facies and grade distribution of the Merensky Reef, Western Bushveld Complex with some mining implications. In: C.R. Anhaeusser (Editor), Proceedings, XVth CMMI Congress. South African Institute of Mining and Metallurgy / Geological Society of South Africa, 3, Geology, 183-194.

Viljoen, M.J. (1999). The nature and origin of the Merensky Reef of the western Bushveld Complex based on geological facies and geophysical data. South African Journal of Geology, 102, 221-239.

Viljoen, M.J., De Klerk, W.J., Coetzer, P.M., Hatch, N.P., Kinloch, E. and Peyerl, W. (1986a). The Union Section of Rustenburg Platinum Mines Limited with reference to the Merensky Reef. In: $C$. R. Anhaeusser and S. Maske (Editors), Mineral Deposits of Southern Africa. Geological Society of South Africa, 1061-1090.

Viljoen, M.J. and Hieber, R. (1986). The Rustenburg Section of Rustenburg Platinum Mines Limited, with reference to the Merensky Reef. In: C.R Anhaeusser and S. Maske (Editors), Mineral Deposits of Southern Africa Geological Society of South Africa, 1107-1134.

Viljoen, M.J., Theron, J., Underwood, B., Walters, B.M., Weaver, J. and Peyerl, W. (1986b). The Amandelbult Section of the Rustenberg Platinum Mines Limited, with reference to the Merensky Reef. In: C.R. Anhaeusser and S. Maske (Editors), Mineral Deposits of Southern Africa. Geological Society of South Africa, 1041-1060.

Von Gruenewaldt, G., Dicks, D., De Wet, J. and Horsch, H. (1990). PGE mineralization in the western sector of the eastern Bushveld Complex. Mineralogy and Petrology, 42, 71-95.

Wilson, A. and Chunnett, G. (2006). Trace element and platinum group element distributions and the genesis of the Merensky Reef, Western Bushveld Complex, South Africa. Journal of Petrology, 47, 2369-2403.

Wood, S.A., Mountain, B.W., and Pan, P. (1992). The aqueous geochemistry of platinum, palladium and gold: Recent experimental constraints and a re-evaluation of theoretical predictions. Canadian Mineralogist, 30, $955-982$.

Editorial handling: A. Bumby 
Copyright of South African Journal of Geology is the property of Geological Society of South Africa and its content may not be copied or emailed to multiple sites or posted to a listserv without the copyright holder's express written permission. However, users may print, download, or email articles for individual use. 